\title{
Switzerland's role as a hotspot of type specimens
}

\author{
Up to a quarter of all the world's species can be found in one small, landlocked country.
}

Sir - Switzerland covers $0.03 \%$ of the world's land surface, and lacks marine or tropical ecosystems. Yet we have found an estimated 345,000 type specimens (used for taxonomic naming of species) in Swiss museums and other collections. According to some estimates, there are about 1.5 million known species in the world. If correct, this means that Switzerland contains type specimens of up to a quarter of all the world's known species.

This exceptional number is surprising, as Switzerland has never been a colonial power, nor does it contain many large natural-history collections like those kept in prestigious institutions elsewhere. The work was done by taxonomists who built up enormous global collections - for example, Augustin-Pyramus de Candolle and his son Alphonse in the nineteenth century, and Auguste Forel, who died in 1931 - and by others who focused on the biological survey of particular areas, such as New Caledonia or Paraguay.

Establishing the exact number of types in Swiss collections is part of an initiative by the Swiss Biodiversity Collections Online Consortium (www.biodiversity. ch/sbc-online.ch) - a consortium of Swiss systematists, curators of biological collections, the Systematics Task Force and the Swiss Biodiversity Forum. The consortium is lobbying the Swiss federal government to invest in this unique resource so it can be made available to the scientific community, with access to visual sources and databases, through the Global Biodiversity Information Facility (GBIF) and other Internet applications.

The type collections are invaluable tools for use in international efforts to document our planet's biodiversity. Not only should they stimulate taxonomists to work on them, but they should surely be important enough for Switzerland to become a full member of GBIF so it can share its wealth with other scientists and conservationists.

This activity may revitalize Swiss national systematics research, which has suffered several recent setbacks. Currently, there are no professors of systematic zoology at any Swiss university, and the country has only two institutes of systematic botany (both with worldwide herbaria), in Geneva and Zurich. It will also provide an excellent incentive to tempt leading foreign scientists to work in Switzerland.

\section{Donat Agosti}

American Museum of Natural History, New York, New York 10024-5192, USA

Peter Linder Institute for Systematic Botany, University of Zürich, 8008 Zürich, Switzerland

Daniel Burckhardt Naturhistorisches Museum, 4001 Basel,

Switzerland

Sylvia Martinez Swiss Biodiversity Forum, Swiss Academy of Sciences, 3003 Bern, Switzerland

Ivan Löbl Muséum d'Histoire Naturelle, 1211 Geneva, Switzerland

Pierre André Loizeau Conservatoire et Jardin Botaniques, 1292 Chambésy/Geneva, Switzerland

\section{Novel and conventional paths to a better banana}

Sir - Your News Feature "A dying breed" (Nature 421, 568-570; 2003) highlights the threat to commercial banana plantations from a strain of Panama disease. Scare stories predicting the imminent end of the banana if this fungal pathogen spreads to Latin America have been blown up out of all proportion in the media (see, for example, New Scientist 26-29, 18 January 2003). Contrary to what has been written, the Panama pathogen with the ability to kill Cavendish (the main commercial subgroup of banana) in the tropics is found only in parts of a few countries, notably Malaysia and Indonesia.

Controls on the international movement of banana planting material should prevent this particular type of Panama from rapidly expanding its distribution. Even if this pathogen strain appears in plantations in Latin America, strict quarantine measures should limit its effects. Neither the export banana, nor any other banana, is in danger of disappearing just yet.

Because of the sterility of Cavendish cultivars, genetic manipulation is seen as the answer to disease problems that afflict this important crop. Although Cavendish is sterile, to label all bananas "sterile mutants" is an unkind exaggeration. Many clones are fertile and have been used in conventional breeding programmes.
New bananas have been successfully created by crossing synthetic diploids (derived from wild species with resistance to disease and pests) with cultivars in need of improvement. Much work has been undertaken at the Honduran Agricultural Research Foundation (FHIA) in the past, and its hybrids have found niches in various countries around the world. Many thousands are grown in Cuba, where chemical disease control is an unaffordable extravagance.

Certainly, the goal of breeding a diseaseresistant replacement for Cavendish, the banana commonly seen in supermarkets, by conventional means has been elusive. However, the development of a new export banana is by no means impossible. The late Phil Rowe hoped to achieve this at FHIA by crossing fertile dwarf variants of 'Gros Michel', the old cultivar of the trades, with his improved diploids. More funding, which is sadly lacking, could still help his dream to be realized.

As reported with other crops, limited funds for banana improvement seem to have been channelled into genomic and genetic transformation work. If consumer objections to genetically modified food can be overcome, this research may have long-term benefits. However, we need to keep all our options open and also support conventional breeding methods.

\section{David Jones}

Editor, Diseases of Banana, Abacá and Enset,

12 Charlotte Brontë Drive, Droitwich Spa,

Worcestershire WR9 7HU, UK

\section{Objective assessment of transgenic salmon}

Sir — In your News item, "Transgenic salmon still out in the cold in the United States" (Nature 421, 304; 2003), you state that Aqua Bounty Farms is working with us "to perform an environmental-impact assessment, which it will use to support its application" to the US Food and Drug Administration for approval of its technology. Although we are discussing such work with Aqua Bounty, we have not yet signed a contract to do this research. More important, we understand that Aqua Bounty intends to submit our analysis as part of its application, but we do not know whether our results will support that application.

Our analysis will be a rigorous, objective, scientifically sound investigation, subject to standard legal separation between academic researchers and their funders. The work will be conducted in collaboration with a panel of scientific experts. Our results will not be shared with Aqua Bounty or regulatory agencies until submitted for publication in a scientific journal. Further, aware of the controversial nature of this issue and to inform the questions we ask and our analysis, our research will receive input from multiple funders with a range of perspectives on the topic of transgenic salmon.

George Gray

Harvard Center for Risk Analysis, 718 Huntington Avenue, Boston, Massachusetts 02115, USA 